\title{
Development of a molecular test to determine the vitality status of Norway spruce (Picea abies) seedlings during frozen storage
}

\author{
Eva Stattin • Nathalie Verhoef • Peter Balk • Monique van Wordragen • \\ Anders Lindström
}

Received: 27 October 2011/Accepted: 19 March 2012/Published online: 4 April 2012

(C) The Author(s) 2012. This article is published with open access at Springerlink.com

\begin{abstract}
In boreal forest regions, a great portion of forest tree seedlings are stored indoors in late autumn to prevent seedlings from outdoor winter damage. For seedlings to be able to survive in storage it is crucial that they store well and can cope with the dark and cold storage environment. The aim of this study was to search for genes that can determine the vitality status of Norway spruce (Picea abies (L.) Karst.) seedlings during frozen storage. Furthermore, the sensitivity of the ColdNSure ${ }^{\mathrm{TM}}$ test, a gene activity test that predicts storability was assessed. The storability of seedlings was tested biweekly by evaluating damage with the gene activity test and the electrolyte leakage test after freezing seedlings to $-25^{\circ} \mathrm{C}$ (the $\mathrm{SEL}_{\text {diff-25 }}$ method). In parallel, seedlings were frozen stored at $-3{ }^{\circ} \mathrm{C}$. According to both methods, seedlings were considered storable from week 41 . This also corresponded to the post storage results determined at the end of the storage period. In order to identify vitality indicators, Next Generation Sequencing (NGS) was performed on bud samples collected during storage. Comparing physiological post storage data to gene analysis data revealed numerous vitality related genes. To validate the results, a second trial was performed. In this trial, gene activity was better in predicting seedling storability than the conventional freezing test; this indicates a high sensitivity level of this molecular assay. For multiple indicators a clear switch between damaged and vital seedlings was observed. A collection of indicators will be used in the future development of a commercial vitality test.
\end{abstract}

Keywords Vitality test · Forest tree seedlings - Storability - Picea abies . Next generation sequencing $\cdot$ Gene expression

\footnotetext{
E. Stattin $(\bowtie) \cdot$ A. Lindström

Dalarna University, 79188 Falun, Sweden

e-mail: esa@du.se
}

N. Verhoef $\cdot$ P. Balk · M. van Wordragen

NSure, Binnenhaven 5, 6700 AA Wageningen, The Netherlands 


\section{Introduction}

The commercially managed forests require a supply of billions of seedlings annually. Historically, many areas have also been left inadequately reforested after cutting and these areas need restoration and therefore are also in the need of a supply of vital seedlings. The coniferous planting stock for reforestation or restoration, annually more than 2 billion seedlings in Northern Europe, USA, and Canada alone, is mainly produced by large scaled forest tree nurseries. This requires a tight scheduling of operations to be able to deliver vital seedlings to the planting site. In late autumn, a great portion of cultured seedlings in Scandinavia are transferred to frozen storage to prevent seedlings from damage caused by low and fluctuating winter temperatures, fungae, or feeding by rodents. In many northern regions there is a substantial risk that roots of container seedlings will be exposed to detrimental low temperatures due to lack of insulating snow cover. Root damage is probably one of the main reasons for deteriorated vitality of outdoor stored container seedlings (Lindström 1986). Besides protection, another advantage with the artificial storage environment is that the resting seedlings become available for planting for an extended period. To survive storage it is crucial that seedlings are in such a state that they can cope with the dark and cold environment (reviewed by Colombo et al. 2001). Seedling storability can be assessed by measurement of dry matter content or water content (Rosvall-Åhnebrink 1985; Calmé et al. 1993), bud dormancy status (Holby et al. 1981), tolerance to freezing by determining electrolyte leakage (Lindström and Håkansson 1996; Colombo 1997; Brönnum 2005), chlorophyll fluorescence and visible damage (Perks et al. 2004; L'Hirondelle et al. 2006) or by measuring gene activity of genes involved in frost hardiness development (Joosen et al. 2006; Balk et al. 2007; Balk et al. 2008). Nevertheless, seedling vitality at the time of delivery may be low even though seedlings were considered storable at the time of storage. Because most storability measurement methods are usually performed on above ground tissues, pre-storage damages to seedling roots may not be recognized. Lindström and Stattin (1994) showed deteriorated vitality of Scots pine (Pinus sylvestris L.) and Norway spruce (Picea abies (L.) Karst.), particularly in frozen storage, when roots had been exposed to freezing before storage. Also, inappropriate storage conditions can negatively affect the vitality in different ways (Aldhous 1964; Webb and von Althen 1980; Ritchie 1982) and fungae infections is often a major problem (Landis 1989; Capieau 2004). Therefore, methods are needed to estimate seedling vitality during frozen storage.

To establish a reliable general measure of seedling quality before seedlings are delivered to the customer is desirable, but hard to obtain. Besides morphological parameters, the vitality of the seedling determines the field performance of the seedling. Numerous morphological (e.g. height, weight, root/shoot ratios) and physiological attributes (e.g. water potential, mineral nutrition, enzymatic activity) have been used and evaluated to predict field performance (reviewed by Mattsson 1997). Nevertheless, none of them has yet proven to be reliable as single test. Combining material (measures directly assessed on the cultivated seedlings) and performance indicators (growth response measurement on seedlings subjected to certain environmental conditions) may result in fairly good predictions of field performance, but the environment that the seedling encounters at the planting site is variable and can never be fully predicted and this makes quality assessments uncertain. Seedling vitality on the other hand, an important part of the quality concept, is measurable. Examples of methods used to detect disturbances within the seedling are electrical methods using electrolytic conductance (McKay 1992; L'Hirondelle et al. 2006), color or spectrophotometric determinations using triphenyl tetrazolium chloride reduction (Parker 1953; 
Lassheikki et al. 1991) or ninhydrin-reactive compounds (Wiest et al. 1976; Bigras and Calmé 1994), xylem pressure potential methods (Waring and Cleary 1967; McCreary 1984), measures of stomatal conductance and photosynthesis (Lindström 1986; Delucia 1987), infrared thermography (Örlander et al. 1989), chlorophyll fluorescence (L'Hirondelle. et al. 2006) and measurement of seedling nutrient status (Rytter and Rytter 2010). Despite a relatively large selection of physiological methods nurseries still commonly practice regrowth tests (Mattsson 1986; 1991) for vitality control. In practice, due to complicated procedures in conducting physiological measures, nurseries often depend on regrowth tests to be able to discover winter damages, despite their disadvantage of being time consuming. Therefore a reliable fast test that would ensure high quality of the delivered seedlings would be of great value.

In 2006, NSure launched onto the market cold-tolerance assays for Douglas-fir (Pseudotsuga menziesii (Mirb.) Franco), Scots pine, and Norway spruce. This test, ColdNSure $^{\mathrm{TM}}$ test, is based on measuring the activity level of a set of genes that are involved in frost hardiness development (Joosen et al. 2006; Balk et al. 2007; Balk et al. 2008). When a gene becomes active, it produces in the nucleus multiple copies of molecules called messenger RNA (mRNA). mRNA is the carrier of genetic information that directs the synthesis of proteins leading to different biological reactions. Because all physiological responses are due to genes switching on or off, any environmental trigger can be followed directly. In the medical field the same technology is used in tumor typing (Landers et al. 2005; Modlich et al. 2005) and the diagnosis of infectious diseases (Helweg-Larsen et al. 1998; Engelmann et al. 2008).

In a Eurostars financed project, Dalarna University and NSure aimed to develop a molecular assay to monitor the vitality status of pine and spruce seedlings during frozen storage. In order to find genes that can determine the vitality status of frozen stored seedlings, use was made of Next Generation Sequencing (NGS). NGS has proven to be a powerful technique and during the last couple of years it has been broadly used in plant science (Zenoni et al. 2010; Severin et al. 2010). The strength of this technology is that no prior sequence information of the plant is needed. This means that any test in any given species can be developed. RNA-Seq, a version of NGS, permits the simultaneous sequencing and quantitation of the RNA content of a sample, better known as the transcriptome. As RNA-Seq gives an unbiased complete overview of all genes that are expressed within the sample it makes it possible to compare samples. RNA-Seq is expensive and not suitable for use in practice, therefore real-time RT-PCR is better to use when monitoring the expression of a selected set of vitality indicator genes.

This paper describes the identification process of vitality related indicators. Furthermore the sensitivity of the gene activity test is compared to the conventional electrolyte leakage test.

\section{Materials and methods}

Plant material and physiological tests

In order to generate Norway spruce seedlings with different levels of vitality, 2 experiments were conducted in which seedlings were frozen stored at $-3{ }^{\circ} \mathrm{C}$ at different calendar dates. To circumvent noise effects that are induced by provenance or age we used 2 different provenances and 2 ages allowing identifying genes that are differentially expressed due to a difference in vitality. The 2 trials were conducted in 2008-2009 in 
Garpenberg $\left(60^{\circ} 15^{\prime} \mathrm{N} ; 16^{\circ} 15^{\prime} \mathrm{E}\right)$ and in $2010-2011$ in Vassbo $\left(60^{\circ} 31^{\prime} \mathrm{N} ; 1^{\circ} 31^{\prime} \mathrm{E}\right)$. In the first trial, 1-year-old Norway spruce seedlings (origin $55^{\circ} 00^{\prime} \mathrm{N}$ ) that had been cultivated at Lugnet nursery $\left(59^{\circ} 38^{\prime} \mathrm{N} ; 17^{\circ} 31^{\prime} \mathrm{E}\right)$ were used. These seedlings were subjected to long night (LN) treatment in the nursery between July 30 and August 25. In the second trial, 1.5-year-old Norway spruce seedlings (origin $60^{\circ} 30^{\prime} \mathrm{N}$ ) cultivated at Nässja nursery $\left(60^{\circ} 16^{\prime} \mathrm{N} ; 16^{\circ} 48^{\prime} \mathrm{E}\right)$ were used.

In both years, the storability of seedlings subjected to ambient conditions outdoors was tested using the SEL $_{\text {diff-25 }}$ method (Lindström and Håkansson 1996; Brönnum 2005) and the gene activity test. When using the $\mathrm{SEL}_{\mathrm{diff}-25}$ method shoots from 15 seedlings, in five replicates, are frozen to $-25{ }^{\circ} \mathrm{C}$ and the damage is evaluated by measurement of the electrolyte leakage from the tissue. The electrolyte leakage from 15 unfrozen seedlings, also in 5 replicates, is then subtracted from the leakage from the frozen shoots. For a seedling batch to be considered storable each replicate has to have a value $\leq 4$ according to Lindström and Håkansson (1996). In the first trial the storability was tested biweekly from week 39 until week 49 and in the second trial seedlings were tested in week 37 and then every week from week 39 until week 45 and again in week 49. Bud samples from the frozen stored seedlings for gene expression analysis were collected in both trials in January (week 3) and in the first trial again in April (week 18). At the end of the storage period (May/June in the first trial and January in the second trial) the vitality of the seedlings was evaluated in a 3-week root growth capacity (RGC) test according to Mattsson (1986). Seedlings showing no signs of new root growth outside the original root substrate were classified as dead. In the second trial the top bud status of the seedlings was also recorded at the end of the RGC test. The buds were subjectively classified as dead, resting $(\leq 1 \mathrm{~cm}$ elongated), or burst ( $>1 \mathrm{~cm}$ elongated). In the first trial 25 seedlings, in 5 replicates, were used in the RGC test and in the second trial 15 seedlings, in 3 replicates, were used. Statistical analyses of differences in seedling survival after storage were made by using the $\chi^{2}$ test (Zar 1974).

Storability assessed by measurement of gene activity

Needle tissue from the top 2-cm of the 1-year-old seedlings was processed according to the sampling protocol provided with the NSure sampling kit. For each seedling group on each test date, needles were sampled from 15 seedlings. Needles were cut into small pieces and transferred to a vial containing extraction fluid, and a pestle was used to crush the tissue in the fluid for about $1 \mathrm{~min}$. Subsequently, 1 drop of extract was transferred to an FTA card and allowed to dry at room temperature. In the case of the 1.5-year-old Norway spruce seedlings, bud tissue, from 25 seedlings, that had been frozen in liquid nitrogen was used. The ColdNSure ${ }^{\mathrm{TM}}$ measures the activity of four genes that change in relation to each other during cold hardiness development. Three should show increased activity, and one should show decreased activity. In addition, 2 control genes for which the activity was expected to remain constant were measured. According to standard protocols, expression levels were measured using real-time RT PCR (iQ5 real-time PCR detection system, Bio-Rad). The corresponding hardiness status was calculated using a model for Norway spruce.

Selection of vitality indicator genes

From the first trial, total RNA was isolated out of 25 frozen buds of 2 affected and 4 vital seedling batches and sent to ServiceXS (The Netherlands) for next generation Illumina sequencing and analysis. The quality and integrity of the RNA samples was analysed on a 
RNA 6000 Lab-on-a-Chip using a Bioanalyzer 2100 (Agiligent Technologies, USA). The Illumina mRNA-Seq Sample Prep Kit was used to process samples. The sample preparation was performed according to the Illumina protocol 'Preparing Samples for Sequencing of mRNA' (1004898 Rev.D). The quality and yield after sample preparation was measured with an Agilent DNA 1000 Lab-on-a-Chip. The size of the resulting products was consistent with the expected size of approximately 200 basepairs. To generate a reference, a Paired-End sequencing run with a length of 50 bases was performed on a vital sample on the Illumina Genome Analyzer IIx. Clustering and DNA sequencing using the Genome Analyzer IIx (Solexa) was performed according manufacturer's protocols. Image analysis, basecalling and quality check was performed with the Illumina Genome Analyzer data analysis pipeline v1.5.1. The reads were assembled into contigs using the de novo assembler PEassembly in the NextGENe v.1.95 (SoftGenetics) package. Assembly resulted in 20071 contigs, with an average length of 806 bp. Assembled contigs were blasted against the Genbank nucleotide (nt) database for annotation (http:// www.ncbi.nlm.nih.gov/genbank/). The reads were aligned onto the assembled contigs using the Tophat v.1.0.13 package (Trapnell et al. 2009). Expression levels were calculated with Cufflinks v0.8.2 (Trapnell et al. 2010). Next, a Single-Read multiplexed sequencing run with a length of 50 bases was performed on all samples. Clustering and DNA sequencing using the Genome Analyzer IIx (Solexa) was performed according manufacturer's protocols. Image analysis, basecalling and quality check was performed with the Illumina Genome Analyzer data analysis pipeline RTA v1.8.70.0 and/or OLB v1.8 and CASAVA v1.7.0. Reads were first mapped to the generated reference obtained in the de novo assembly stage. Quantification of a gene was performed by counting the number per read per gene of each sample. For differential analysis between the samples DESeq (http://www.huber.embl.de/users/anders/-DESeq/) was used with a Pvalue cutoff of $<0.1$. Subsequently, a selection of potential vitality indicators was selected and specific primers were designed using Primer3 (http://frodo.wi.mit.edu/primer3/). Expression levels of all collected frozen bud samples from the first and second trial were measured using real-time RT PCR (iQ5 real-time PCR detection system, Bio-Rad) using standard protocols. In case for the 1.5-year-old seedlings, Pearson correlation coefficients were independently calculated for each upregulated vitality gene versus the root or shoot growth. The significance of each correlation coefficient was determined by using the critical value table for Pearson's Correlation Coefficient with a level of significance of 0.01 (http://www.gifted.uconn.edu/ siegle/research/Correlation/corrchrt.-htm).

\section{Results}

Development of freezing tolerance and storability

According to the $\mathrm{SEL}_{\mathrm{diff}-25}$ measurements, 1-year-old seedlings from the first trial were considered storable in week 41 , i.e. all replicates were $\leq 4$ (Fig. 1a). The gene activity test gave the same outcome, the transcript level of indicator $\mathrm{COl}$ turned in week 41 from positive to negative, an indication point at which seedlings are considered to be storable (Fig. 1c). In the second trial freezing tolerance and storability, measured as $\mathrm{SEL}_{\mathrm{diff}-25}$, increased from week 37 to week 43 and stayed at this level throughout the observation period (Fig. 1b). According to this measurement all replicates were $\leq 4$ in week 43 and thereby considered storable. According to the gene activity test, seedlings were considered storable from week 42 (Fig. 1d). 

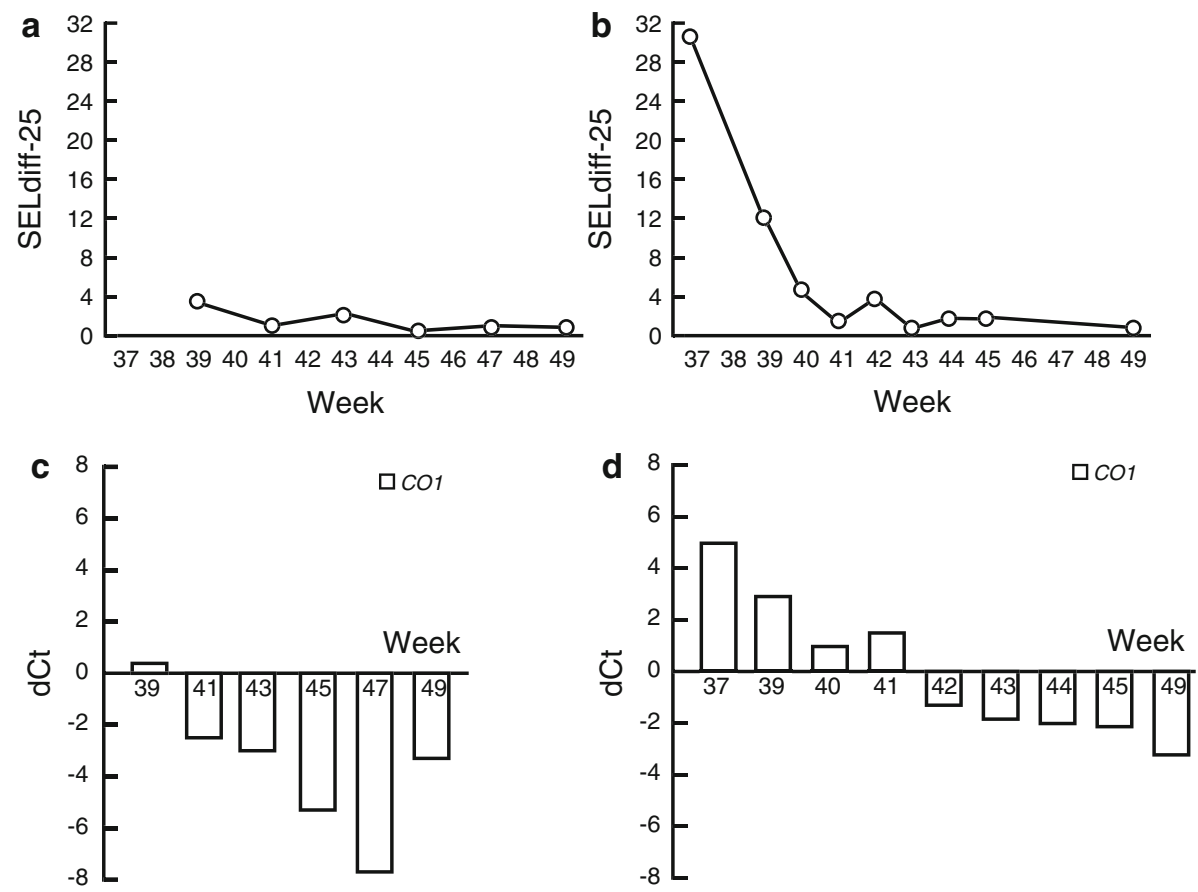

Fig. 1 Determining freezing tolerance of Norway spruce seedlings. Freezing tolerance of seedlings grown outdoors of 1-year-old (a, c) and 1.5-year-old $(\mathbf{b}, \mathbf{d})$ seedlings was measured by SEL $\mathrm{diff}_{25}(\mathbf{a}, \mathbf{b})$ (standard error of treatment mean $0.07-1.08$ and $0.18-1.96$ respectively) and gene activity (ColdNSure ${ }^{\mathrm{TM}}$ ) (c, d) at different calendar dates. Expression of gene activity indicator $C O 1$, was given as $\mathrm{dC}_{\mathrm{T}}$, the cycle threshold $\left(\mathrm{C}_{\mathrm{T}}\right)$ difference between two genes. $\mathrm{N}=5\left(\mathrm{SEL}_{\mathrm{diff}-25}\right)$

The results from the RGC tests performed after the storage period with the 1-year-old seedlings showed that seedlings put into storage week 41 and later were vital at the end of the storage period (Figs. 2a, c and 3a, c). These seedlings showed significantly higher survival $(p<0.0001)$ than seedlings stored earlier and they also showed shoot and root growth. The storage results concerning the 1.5-year-old seedlings shows significantly higher $(p<0.0001)$ survival rates for seedlings stored after week 39 (Fig. 2d). However, poor top bud status (Figs. 2b and 4) as well as absence of shoot growth (Fig. 3b) indicates decreased vitality for seedlings stored in week 40 and 41 . Seedlings stored in week 42 and thereafter are vital, producing shoot and root growth in the RGC tests performed after the storage period.

Global analysis of genes involved in vitality

To characterize gene expression changes that are vitality related, Illumina RNA-Seq was used. RNA-Seq using the Genome Analyzer IIx (Solexa) was performed on seedlings from week 39 and 49 from the first trial prior to storage and during storage. Differential expression analysis on the raw counts was performed by DESeq, a model based on negative bionomial distribution. To minimize false negatives and positives, only differential genes were selected with a log2fold change higher than 5. In total, 186 genes were found to be differentially expressed, of which most (165) were up-regulated and 21 down regulated. 

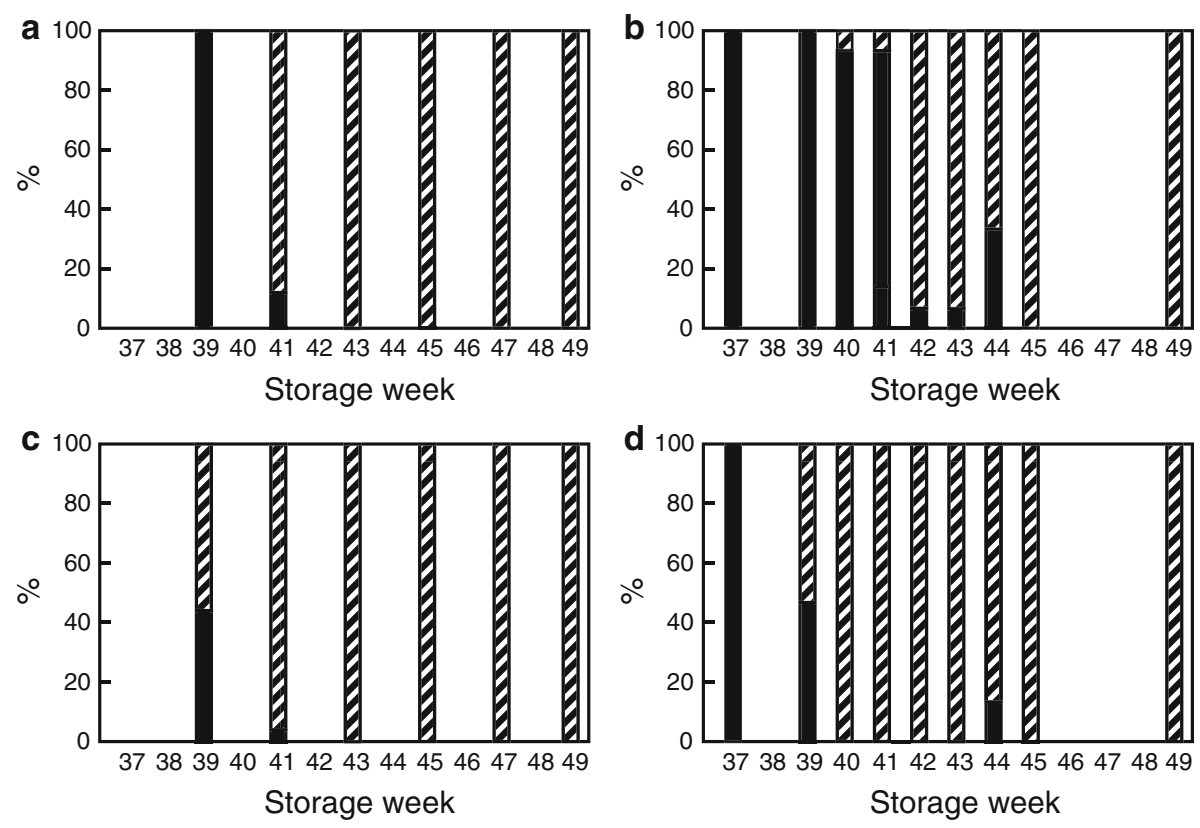

Fig. 2 Percentage of Norway spruce seedlings with (shading) and without (black) shoot (a, b) and root (c, d) growth in 3-week growth tests performed in May with 1-year-old (a, c) and in January with 1.5-year-old (b, d) seedlings after frozen $\left(-3{ }^{\circ} \mathrm{C}\right)$ storage. The seedlings were put into storage at the indicated weeks. $\mathrm{N}=25$ (1-year); $\mathrm{N}=15$ (1.5-year)
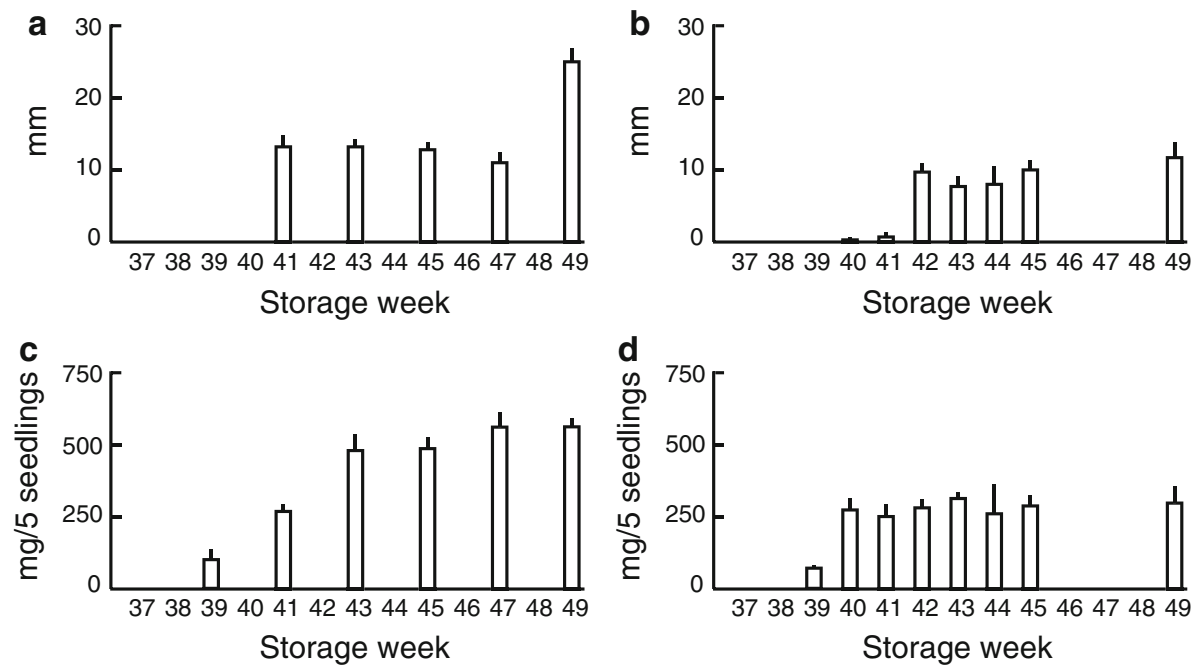

Fig. 3 Shoot growth, mm, (a, b) and root growth, mg/5 seedlings, (c, d) capacity of Norway spruce seedlings in 3-week growth tests performed in May with 1-year-old (a, c) and in January with 1.5-year-old (b, d) seedlings after frozen $\left(-3{ }^{\circ} \mathrm{C}\right)$ storage. The seedlings were put into storage at indicated weeks. Error bars denote standard errors. $\mathrm{N}=25$ (shoot 1-year); $\mathrm{N}=15$ (shoot 1.5-year); $\mathrm{N}=5$ (root 1-year); $\mathrm{N}=3$ (root 1.5-year) 
Fig. 4 Classification of the top bud status, \%, of 1.5-year-old Norway spruce seedlings at the end of a RGC test performed in January after frozen storage. The seedlings were put into storage at the indicated weeks. Dead (black), resting (white) and burst (shading) top bud. $\mathrm{N}=15$

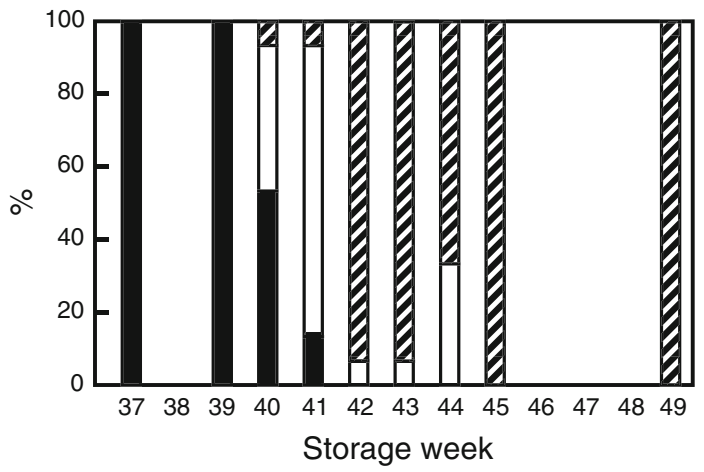

b
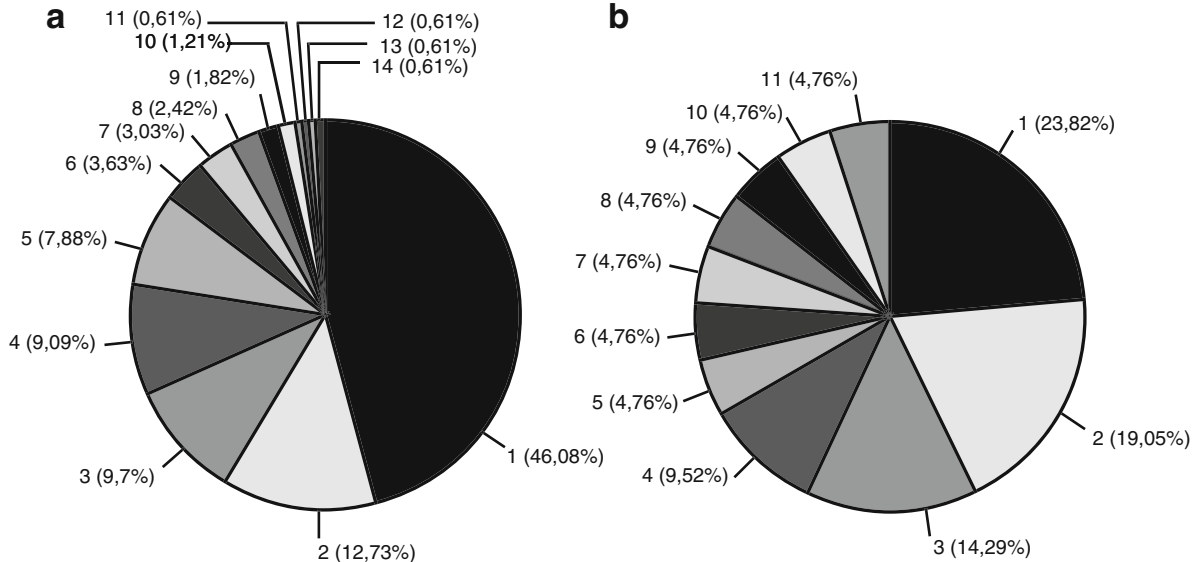

Fig. 5 Classification of the most highly up-regulated and down-regulated genes. The pie chart (a) for upregulated (165) genes is classified in: (1) unclassified genes (2) cell defence (3) metabolism (4) classification unclear (5) signal transduction (6) transcription (7) cellular transport (8) energy (9) no significant similarity (10) photosynthesis (11) DNA processing (12) protein synthesis (13) cell wall (14) protein metabolism. The pie chart (b) for down-regulated (21) genes is classified in: (1) unclassified genes (2) metabolism (3) cell defence (4) classification unclear (5) signal transduction (6) transcription (7) photosynthesis (8) cellular transport (9) no significant similarity (10) cell wall (11) DNA processing

Gene ontology analysis revealed that most of the genes share close homology to genes from other plant species with an unknown function or solely matched with spruce Expressed Sequence Tag (EST) sequences (unclassified genes, Fig. 5a, b). This implies that these undescribed genes might play a role in vitality and hardening related processes. For several genes it was difficult to classify their functional category so they were classified as 'classification unclear' (Fig. 5a, b). In the case of a couple of down regulating genes, no significant similarity to any sequence in the Genbank nt database was found (no significant similarity, Fig. 5b). The genes that could be grouped into functional categories were involved in metabolism (e.g. genes involved in the biosynthesis of sugars, amino acids or lignin), cell defense (e.g. Heat Shock Proteins (HSPs), antifreeze genes such as dehydrins and pathogenesis-related genes), signal transduction pathways (hormonal), transcription, and cellular transport (Fig. 5a, b). 
Validation of RNA-Seq based gene expression

To validate the expression profiles obtained by RNA-Seq, real time RT-PCR was performed on respectively 17 and 11 genes that were positively and negatively correlated to vitality. They were chosen based on their putative function and/or high difference in expression. For 24 genes, real time RT-PCR expression profiles were in complete agreement with the RNA-Seq data and showed the desired expression pattern. In the first trial, buds were collected at week 3 and 18 from seedlings that went to frozen storage between week 39 and 49. The transcripts of VII, VI2 and VI3, all categorized as unclassified (Fig. 5a), were up regulated when seedlings were stored later in autumn (Fig. 6a). Interestingly, expression of the 3 genes dropped during storage (Fig. 6a). In case of the second trial, samples were only collected at week 3 . A very clear switch in gene expression was encountered between week 41 and 42, the moment when seedlings were considered storable with the gene activity test (Fig. 6b). The expression levels of VII-VI3 at week 3 from the second trial were remarkably lower when compared to the seedlings from week 3 of the first trial. The expression levels were more comparable with the expression levels measured in week 18 (Fig. 6a, b). Indicators VI4 and VI5, respectively categorized in cellular transport and cell defence (Fig. 5b), showed a clear decreasing trend when seedlings were stored later in autumn (Fig. 6c, d). The expression of VI4 and VI5 was more

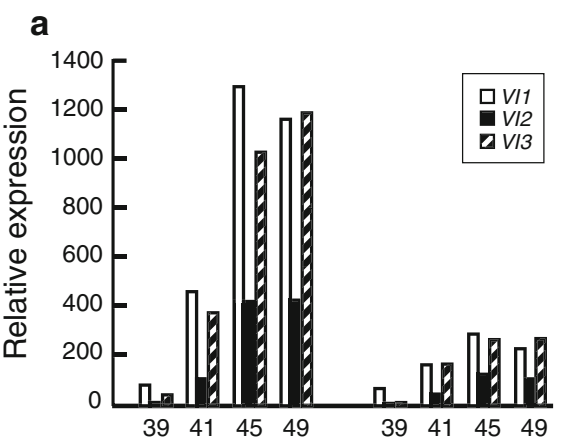

Storage week 3 Storage week 18

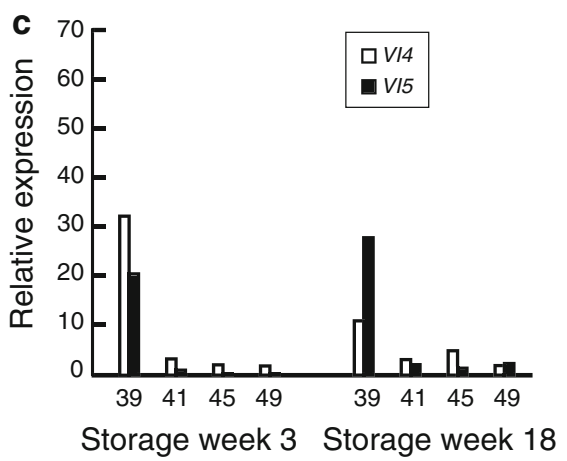

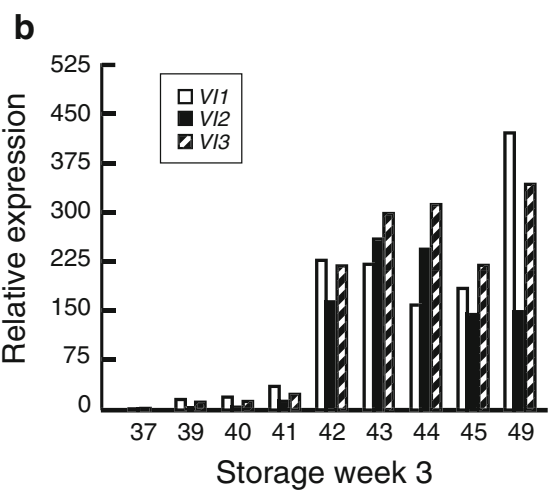

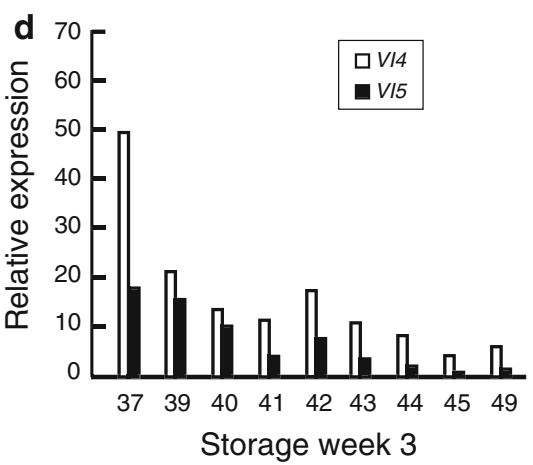

Fig. 6 Gene expression profiles related to vitality of Norway spruce seedlings during frozen storage. Seedlings were stored at different calendar dates (week 37-49). For gene expression analysis, buds were collected in week 3 and 18 from 1-year-old (a, c) and in week 3 from 1.5-year-old (b, d) stored seedlings. The gene expression levels of VII, VI2,VI3 (a, b) and VI4, VI5 (c, d) are relative to internal standards 
Fig. 7 Gene expression and root and shoot growth for 1.5-year-old spruce seedlings that were stored at different calendar dates (week 37-49). For gene expression analysis, buds were collected from stored seedlings at week 3 . Gene expression levels of VI1, $\mathrm{VI} 2, \mathrm{VI} 3$ relative to internal standards are shown together with the shoot growth, $\mathrm{mm}$ (a) and root growth, $\mathrm{mg} / 5$ seedlings (b) which were determined in a 3-week growth test performed in January. The standard error bars for the shoot and root growth are depicted in Fig. $3 b$, d. $\mathrm{N}=15$ (shoot 1.5 year) $\mathrm{N}=3$ (root 1.5-year)
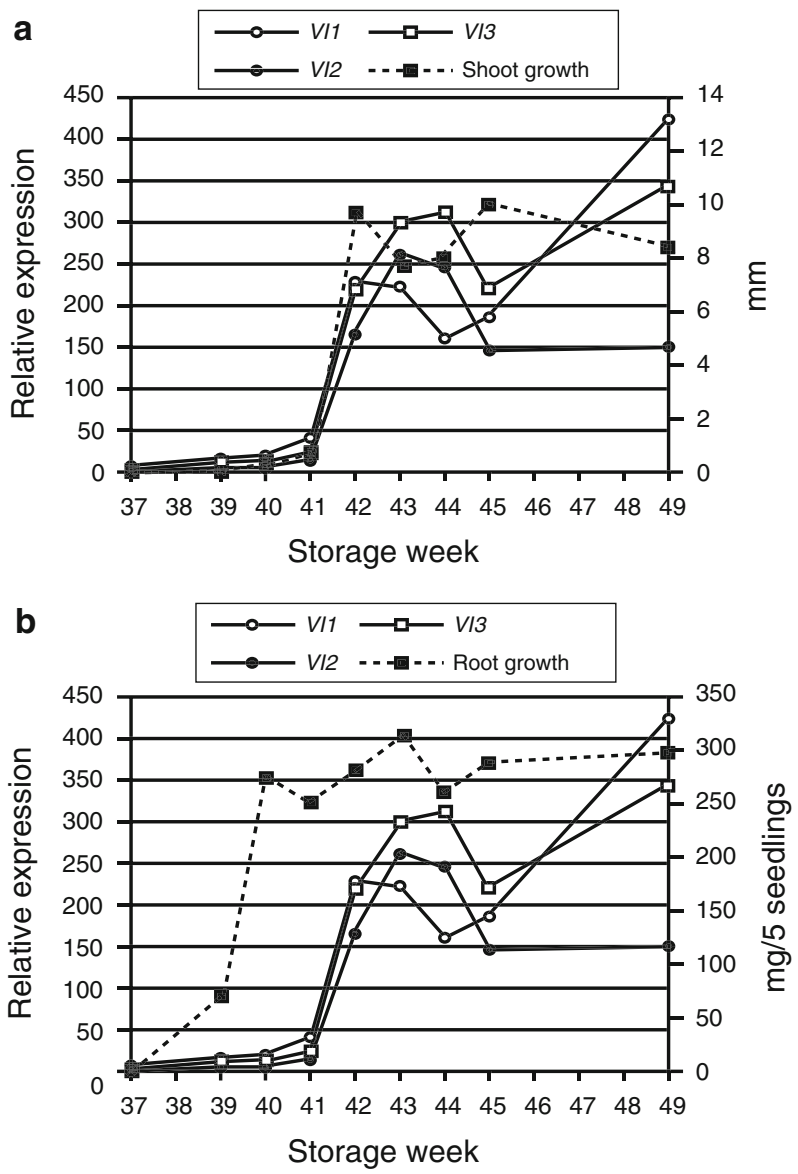

strongly downregulated in the first trial (Fig. 6c, d). Comparison of the physiological and molecular responses revealed that all three upregulated genes (VII-VI3) correlated well with the shoot growth, but poorly with the root growth after storage (Fig. 7a, b). Significant $(p=0.01)$ Pearson correlations were obtained for the vitality genes (VI1-VI3) in relation to the shoot growth $(0.816-0.938)$, whereas no significant correlations were found between the gene activity of VII-VI3 and root growth (0.618-0.661).

\section{Discussion}

The general pattern of increasing freezing tolerance in autumn has been shown for several coniferous species (reviewed by Bigras and Colombo 2001). In our study this pattern is clearly shown for the 1.5-year-old seedlings, but less evidently for the 1-year-old seedlings

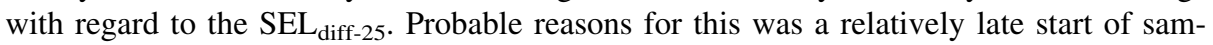
pling combined with the fact that the 1-year-old seedlings were LN treated for almost 4 weeks before the freezing tests were performed. $\mathrm{LN}$ treatment is known to effectively induce growth termination, bud set, and increased shoot freezing tolerance in Norway spruce (Dormling 1993). LN treatments are used in practice to deliver frost tolerant 
seedlings for early autumn planting or to store seedlings in a safe way in frozen storage. Most likely, the 1-year-old seedlings became earlier frost tolerant due to the LN treatment.

Frozen storage of seedlings that have not reached the physiological state needed for frozen storage will cause great losses for the nursery. Therefore the search for methods that can be used to predict storability is important. In the past few years the gene activity test has been proven to be a reliable, robust, and fast method to predict storability. The development of the method was a cooperative research between University of Wageningen, Dalarna University and NSure. This study shows that gene expression profiles related to the development of frost tolerance might be even more sensitive in describing storability in comparison to conventional freezing tolerance tests. In the trial with the 1.5-year-old seedlings, the gene activity test accurately predicted the storability of the seedlings whereas the freezing tolerance test, $\mathrm{SEL}_{\mathrm{diff}-25}$ method, was not able to pinpoint the earliest week of safe storage. The post storage vitality tests showed that seedlings were storable in week 42 , but the $\mathrm{SEL}_{\text {diff-25 }}$ method indicated week 43 as the first week that seedlings were ready for storage. The discrepancy between the 2 methods may indicate that the $\mathrm{SEL}_{\mathrm{diff}-25}$ method is too rigorous. When developing the $\mathrm{SEL}_{\mathrm{diff}-25}$ method, Lindström and Håkansson (1996), to ensure a margin on the prediction of seedling storability, chose to accept very small differences in leakage between frozen and unfrozen seedlings and they also selected a very low freezing temperature. The sensitivity to detect changes in seedling status at an early point is a great advantage for gene activity tests. In addition, the seedlings are sampled in their actual environment and can be analyzed within $24 \mathrm{~h}$. It can also be considered to be an advantage for nurseries selling their products on an open market to use objective and independent organisations for quality measurements.

RNA-Sequencing was used to select indicators for establishing the vitality of seedlings during storage and our study supports that RNA-Seq is a powerful method to reveal genes that are differentially expressed among samples. RNA-Seq revealed 186 candidate genes that might be used to determine vitality during frozen storage. The expression of $\sim 84 \%$ of these genes raised, i.e. the genes were upregulated, once seedlings were stored later in autumn. Only $\sim 16 \%$ of the genes declined. As many genes that play a role in cold response, adaptation and hardening processes should be induced, it is not unexpected that the majority of the differentially expressed genes are higher expressed in vital seedlings. Classification of genes with a known function appeared to function in metabolism, stress, signal transduction, transcription, cell defense, and cellular transport. Although certain groups were more abundant, it does not necessarily indicate the importance of one group over another. Genes corresponding to cell defence included known antifreeze genes, such as dehydrins and pathogenesis-related genes like IV chitinase, $\beta$-1-3-glucanase and thaumatin-like genes (reviewed by Gómez et al. 2005; Joosen et al. 2006). Furthermore genes encoding HSPs were induced in response to cold stress. HSPs act as strong cryoprotectors by participating in membrane protection, refolding of denatured proteins, and act against protein aggregation (reviewed by Gómez et al. 2005). Higher proportions of differentially regulated genes were found to be involved in metabolism. The transcript level of several genes associated with sugar, amino acid, lignin, and secondary metabolism were positively correlated with the freezing tolerance status. Soluble sugars have been shown to play an important role, in the protection of cellular membranes and act as osmoprotectants and primary messengers in signal transduction pathways (Wanner and Juntilla 1999; Hincha et al. 2000; Smeekens 2000; reviewed by Gómez et al. 2005; Yuanyuan et al. 2009). Lowtemperature stress influences the metabolism of nitrogenous compounds, in particular certain amino acids and polyamine compounds (Mazzucotelli et al. 2006; Davey et al. 2009). For instance in several plant species it was shown that proline accumulates in 
response to cold stress (Yelenosky 1979; Jouve et al. 1993; Odlum et al. 1993). Several genes involved in signal transduction were found to be differentially expressed. Interestingly, this included also genes of which it is known that they function in hormonal signal transduction pathways, such as the abscisic acid (ABA) transduction pathway. Biochemical and genetic studies in the past have shown that ABA is increased when exposed to a low temperature and triggers processes leading to increased frost tolerance (Marek et al. 1992; reviewed by Gómez et al. 2005; Joosen et al. 2006). Cell wall modification is necessary to protect the cell against freeze-induced stress. Not surprisingly, several cell wall associated genes were found to be differentially expressed, such as genes which are involved in cell wall loosening and genes which are involved in the production of lignin. The achieved RNAseq data clearly showed that the vitality of the seedling has a complex character involving the regulation of multiple genes involved in various processes.

In this study a significant correlation between the selected vitality genes and the actual vitality estimated as shoot growth at the end of storage was obtained. Regarding the top bud status, $93.3 \%$ of the seedlings stored from week 42 flushed, while $80 \%$ of the seedlings stored a week earlier did not flush and $13.3 \%$ of the seedlings had dead top buds. The lower correlation between expression of the selected vitality genes and root growth could be expected because the vitality genes only were selected from shoot tissue. It is well known that shoots and roots can develop freezing tolerance partly independent of each other (Bigras et al. 2001) which motivates further research to root specific vitality genes. As far as we know this is the first attempt to relate gene expression to vitality and the results open up possibilities to create an assay which would provide a rapid and user friendly technique to assess seedling vitality. Our study was restricted to 1 species, 2 provenances and 2 seedling ages that were differently cultivated. In case of the 1-year-old seedlings expression levels of the 3 upregulating genes (VII-VI3) were much higher expressed during storage at week 3 when compared to the 1.5-year-old seedlings (Fig. 6 a, b). This could be an effect of the LN treatment, which was also encountered by the gene activity test as the indicator level of $\mathrm{CO} 1$ dropped more strongly for the 1-year-old seedlings than the 1.5-year-old seedlings (Fig. $1 \mathrm{c}$, d). Further research is needed to evaluate how the absolute level of gene expression is affected by different factors such as treatments in the nursery, age and provenance.

Acknowledgments This study was made possible by the support from Svenska Skogsplantor AB and funding from the Eureka Eurostar Programme. We wish to thank Marianne Vemhäll for technical support in laboratory work.

Open Access This article is distributed under the terms of the Creative Commons Attribution License which permits any use, distribution, and reproduction in any medium, provided the original author(s) and the source are credited.

\section{References}

Aldhous JR (1964) Cold storage of forest nursery plants. An account of experiments and trials 1958-1963. Forestry 37:47-63

Balk PA, Brönnum P, Perks M, Stattin E, van der Geest LJM, van Wordragen M (2007) Innovative cold tolerance test for conifer seedlings. USDA Forest Service Proceedings RMRS-P-50, pp 9-14

Balk PA, Haase DL, Van Wordragen MF (2008) Gene activity test determines cold tolerance in Douglas-fir seedlings. USDA Forest Service Proceedings RMRS-P-57, pp 140-148

Bigras FJ, Calmé S (1994) Viability tests for estimating root cold tolerance of black spruce seedlings. Can J For Res 24:1039-1048 
Bigras FJ, Colombo SJ (2001) Conifer cold hardiness. Kluwer, Dordrecht

Bigras FJ, Ryyppö A, Lindström A, Stattin E (2001) Cold acclimation and deacclimation of shoots and roots of conifer seedlings. In: Bigras FJ, Colombo SJ (eds) Conifer cold hardiness. Kluwer, Dordrecht, pp 57-89

Brönnum P (2005) Assessment of seedling storability of Quercus robur and Pinus sylvestris. Scand J For Res 20:26-35

Calmé S, Margolis HA, Bigras FJ (1993) Influence of cultural practices on the relationship between frost tolerance and water content of containerized black spruce, white spruce, and jack pine seedlings. Can J For Res 25:503-511

Capieau K (2004) Biological control of grey mould in Swedish forest nurseries. Dissertation, Sweden University of Agricultural Sciences

Colombo SJ (1997) Frost hardening spruce container stock for overwintering in Ontario. New For 13:449-467

Colombo SJ, Menzies MI, O’Reilly C (2001) Influence of nursery cultural practices on cold hardiness of coniferous forest tree seedlings. In: Bigras FJ, Colombo SJ (eds) Conifer cold hardiness. Kluwer, Dordrecht, pp 223-252

Davey MP, Woodward FI, Quick WP (2009) Intraspecific variation in cold-temperature metabolic phenotypes of Arabidopsis lyrata ssp. petraea. Metabolomics 5:138-149

Delucia EH (1987) The effect of freezing nights on photosynthesis, stomatal conductance and internal CO2 concentrations in seedlings of Engelmann spruce (Picea engelmannii Parry). Plant, Cell Environ 10:333-338

Dormling I (1993) Bud dormancy, frost hardiness, and frost drought in seedlings of Pinus sylvestris and Picea abies. In: Li PH, Christersson L (eds) Advances in plant cold hardiness. CRC Press, Boca Raton, Florida, pp s285-s298

Engelmann I, Petzold DR, Kosinska A, Hepkema BG, Schulz TF, Heim A (2008) Rapid quantitative PCR assays for the simultaneous detection of herpes simplex virus, varicella zoster virus, cytomegalovirus, Epstein-Barr virus, and human herpesvirus 6 DNA in blood and other clinical specimens. Med Virology 80:467-477

Gómez L, Allona I, Ramos A, Núñez P, Ibáñez C, Casado R, Aragoncillo C (2005) Molecular responses to thermal stress in woody plants. Invest Agrar Sist Recur For 14(3):307-317

Helweg-Larsen J, Jensen JS, Benfield T, Svendesen UG, Lundgren JD, Lundgren B (1998) Diagnostic use of PCR for detection of Pneumocystis carinii in oral wash samples. J Clin Microbiol 36:2068-2072

Hincha DK, Hellwege EM, Heyer AG, Crowe JH (2000) Plant fructans stabilize phosphatidylcholine liposomes during freeze-drying. Eur J Biochem 267:535-540

Holby HR, Askren CA, Hermann RK (1981) Does the oscilloscope technique reveal the dormancy status of Douglas-fir and ponderosa pine? For Science 27:405-412

Joosen RVL, Lammers M, Balk PA, Brönnum P, Konings MCJM, Perks M, Stattin E, Van Wordragen MF, Van der Geest LHM (2006) Correlating gene expression programs to physiological parameters and environmental conditions during cold acclimation of pine (Pinus sylvestris). Tree Physiol 26: 1297-1313

Jouve L, Engelmann F, Noiret M, Charrier A (1993) Evaluation of biochemical markers (sugar, proline, malonedialdehyde and ethylene) for cold sensitivity in microcuttings of two coffee species. Plant Sci 91:109-116

L'Hirondelle SJ, Simpson DG, Binder WD (2006) Overwinter storability of conifer planting stock: operational testing of fall frost hardiness. New For 32:307-321

Landers KA, Burger MJ, Tebay MA, Purdie DM, Scells B, Samaratunga H, Lavin MF, Gardiner RA (2005) Use of multiple biomarkers for a molecular diagnosis of prostate cancer. Int J Cancer 114:950-956

Landis TD (1989) Disease and pest management. In: Landis TD, Tinus RW, McDonald SE, Barnett JP (eds) The container tree nurs manual vol. 5. US Department of Agricultural. Agric Handbook 674, pp 1-99

Lassheikki M, Puttonen P, Räsänen PK (1991) Planting performance potential of Pinus sylvestris seedlings as evaluated by root growth capacity and triphenyl tetrazolium chloride reduction methods. Scand J For Res 6:91-104

Lindström A (1986) Freezing temperatures in the root zone-effects on growth of containerized Scots pine and Norway spruce seedlings. Scand J For Res 1:371-377

Lindström A, Håkansson L (1996) EC-metoden-ett sätt att bestämma skogsplantors lagringsbarhet. Sweden University of Agricultural Sciences, Dep For Yield Res. Stencil Nr 95 (In Swed)

Lindström A, Stattin E (1994) Root freezing tolerance and vitality of Norway spruce and Scots pine seedlings; influence of storage duration, storage temperature and pre-storage root freezing. Can J For Res 24:2477-2484 
Marek P, Kubik J, Buta G, Wang CY (1992) Changes in the levels of abscisic acid and its metabolites resulting from chilling of tomato fruits. Plant Growth Regul 11:429-434

Mattsson A (1986) Seasonal variation in root growth capacity during cultivation of container grown Pinus sylvestris seedlings. Scand J For Res 1:473-482

Mattsson A (1991) Root growth capacity and field performance of Pinus sylvestris and Picea abies seedlings. Scand J For Res 6:105-112

Mattsson A (1997) Predicting field performance using seedling quality assessment. New For 13:227-252

Mazzucotelli E, Tartari A, Cattivelli L, Forlani G (2006) Metabolism of $\gamma$-aminobutyric acid during cold acclimation and freezing and its relationship to frost tolerance in barley and wheat. J Exp Bot 57:3755-3766

McCreary DD (1984) Using a pressure chamber to detect damage to seedlings accidentally frozen during cold storage. USDA Forest Services, Genetic Technological Report INT-168, pp 58-60

McKay HM (1992) Electrolyte leakage from fine roots of conifer seedlings: a rapid index of plant vitality following cold storage. Can J For Res 22:1371-1377

Modlich O, Prisack HB, Munnes M, Audretsch W, Bojar H (2005) Predictors of primary breast cancers responsiveness to preoperative Epirubicin/Cyclophophamide-based chemotherapy: translation of microarray data into clinically useful predictive signatures. J Translat Medicine 3:1-18

Odlum KD, Blake TJ, Kim YT, Glerum C (1993) Influence of photoperiod and temperature on frost hardiness and free amino acid concentrations in black spruce seedlings. Tree Physiol 13(3):275-282

Örlander G, Egnell G, Forsén S (1989) Infrared thermography as means of assessing seedling quality. Scand J For Res 4:215-222

Parker J (1953) Some applications and limitations of tetrazolium chloride. Science 118:77-79

Perks MP, Osborne BA, Mitchell DT (2004) Rapid predictions of cold tolerance in Douglas-fir seedlings using chlorophyll fluorescence after freezing. New For 28:49-62

Ritchie GA (1982) Carbohydrate reserves and root growth potential in Douglas-fir seedlings before and after cold storage. Can J For Res 12:905-912

Rosvall-Åhnebrink G (1985) Invintring av plantor för höstplantering eller vinterlagring. Sweden University of Agricultural Sciences, Skogsfakta, Konferens 7:33-37. (In Swed)

Rytter R-M, Rytter L (2010) Root preparation technique and storage affect results of seedling quality evaluation in Norway spruce. New Forest 39:355-368

Severin AJ, Woody JL, Bolon Y, Joseph B, Diers BW, Farmer AD, Muehlbauer GJ, Nelson RT, Grant D, Specht JA, Graham MA, Cannon SB, May GD, Vance CP, Shoemaker RC (2010) RNA-Seq Atlas of Glycine max: a guide to the soybean transcriptome. BMC Plant Biol 10:1-16

Smeekens JCM (2000) Sugar-induced signal transduction in plants. Annu Rev Plant Phys Plant Mol Biol 51:49-81

Trapnell C, Pachter L, Salzberg SL (2009) TopHat: discovering splice junctions with RNA-Seq. Bioinformatics 25:1101-1111

Trapnell C, Williams BA, Pertea G, Mortazavi AM, Kwan G, van Baren MJ, Salzberg SL, Wold B, Pachter L (2010) Transcript assembly and quantification by RNA-Seq reveals unannotated transcripts and isoform switching during cell differentiation. Nat Biotechnol 28:511-515

Wanner LA, Juntilla O (1999) Cold-induced freezing tolerance in Arabidopsis. Plant Physiol 120:391-400

Waring RH, Cleary BD (1967) Plant moisture stress: evaluation by pressure bomb. Science 155:1248-1254

Webb DP, von Althen FW (1980) Storage of hardwood planting stock, effects of various storage regimes and packaging methods on root growth and physiological quality. N Z J For Sci 10:83-96

Wiest SC, Good GL, Steponkus PL (1976) Evaluation of root viability following freezing by the release of ninhydrin-reactive compounds. HortSci 11:197-199

Yelenosky G (1979) Accumulation of free proline in citrus leaves during cold hardening of young trees in controlled temperature regimes. Plant Physiol 64:425-427

Yuanyuan M, Zhang Y, Jiang L, Hongbo S (2009) Roles of plant soluble sugars and their responses to plant cold stress. African J Biotech 8:2004-2010

Zar J (1974) Biostatical analyses. Prentice-Hall, Inc., Englewood Cliffs

Zenoni S, Ferrarini A, Giacomelli E, Xumerle L, Fasoli M, Malerba G, Bellin D, Pezzotti M, Delledonne M (2010) Characterization of transcriptional complexity during berry development in Vitis vinifera using RNA-Seq. Plant Physiol 152:1787-1795 